\title{
水循環解析による都市化域での水資源賦存量評価 \\ EVALUATION OF WATER RESOURCES IN AN URBANIZED AREA BY HYDROLOGICAL CYCLE ANALYSIS
}

\author{
才田進 ${ }^{1} \cdot$ 高橋研 $^{2} \cdot$ 神野健二 ${ }^{3} \cdot$ 濱里学 $^{4} \cdot$ 下大迫博志 ${ }^{4}$ \\ Susumu SAITA, Ken TAKAHASI, Kenji JINNO, Manabu HAMAZATO and Hirosi SIMOOSAKO \\ 1 正会員 八千代エンジニヤリング (株) 総合事業本部河川部（干161-8575 東京都新宿区西落合2-18-12） \\ 2 大野城市役所建設部公園街路課（元上下水道局企業総務課）（广816-8510 大野城市曙町2-2-1） \\ 3 正会員 工博 九州大学大学院教授 工学研究院環境システム科学研究センター（†812-8581 福岡市東区箱崎6-10-1） \\ 4 八千代エンジニヤリング (株) 九州支店 技術第一部（广810-0062 福岡市中央区荒戸2-1-5）
}

\begin{abstract}
With the development of urbanization since the 1960's, infiltration and recharge of rainwater into the aquifer systems decreased drastically. Increase in the population also created a difficult situation for supplying sufficient water resources to the urbanized area. Therefore, effective utilization of water resources and development of unused water in the regional scale should be studied. A conventional hydrological cycle model combining the rain water recharge tanks with the quasi-three dimensional groundwater flow model was developed taking account of the land use and geological conditions.

The development of regional water resources was discussed by using the present model. Various hydrological components of the water balance estimation in the study area were clarified. It was concluded from the present study that the proposed conventional model is useful and applicable for making a plan of water management.
\end{abstract}

Key Words : hydrological cycle model , groundwater recharge model, water balance

\section{1.はじめに}

1960 年代半ばからの高度経済成長期を通じての都市 化は，地下水涵養域である水田や森林の減少と建物や舗 装等による不浸透域の急拡大を招き, 人口集中による水 需要量の増大は, 都市活動に不可欠な水資源を自行政区 域内だけで賄うことをできなくしてきた．水資源の市域 外依存率が高くなるに従って, 遠方の水源流域の気象や 水資源事情に影響されることになり，水行政上の不確実 性が増大してきている.

ダムによる従来型の水資源開発は，市民の自然環境保 全への意識高揚により，難しくなって来ており，流域内 の水の循環過程で, 未利用の水資源の開発や有効利用に よる自己水源率の向上が求められている.

降雨流出の物理機構を組み込んだ水循環モデルには, 流域を三次元的に表現したメッシュ型多層流出モデルと して, 土研分布モデル ${ }^{1)}$ やHydro-BEAM ${ }^{2}$ 等がある. これ らのモデルは，地盤水理定数を含め, 多種類のモデル定 数を設定しなくてはならない.このため、調査の初期段 階に得られる限られた調査データからモデル構築が比較
的容易なモデルが現実的である. 本研究は，市域全体の 水収支の評価が可能で，土地利用特性を考慮した簡便な 水循環モデルを提案するものである.

\section{2. 研究対象地域の概要}

研究対象地域は, 図-1 のように福岡市の南に位置し, 住宅都市として発展してきた面積 $26.9 \mathrm{~km}^{2}$ の市域で, 人 口は, 1970 年代から大規模な住宅開発が活発化した結果, 市制施行の 1972 年から 2002 年の 30 年間に, 約 2.4 倍の 91,800 人に急増した. 水道水源は, 約 45\%を地下水に, 約 30\%を広域導水に依存している。広域導水は, 1978 年渇水を教訓に整備されたが, 1994〜95 年の大渇水時に は，再び281 日間に及ぶ給水制限を経験した。

本地域は, 福岡平野の南西地域に位置し, 北東から連 なる三郡山地と南西から連なる脊振山地に挟まれた地域 で，北流する御笠川沿いに延びる狭長な沖積低地とその 周辺に丘陵, 台地が広がる. 地質は, 中生代白亜紀の花 崗岩類を基盤岩とし, 御笠川や牛頸川沿いに, 層厚が最 大 20〜30mほどの第四紀の堆積岩類が分布する. 


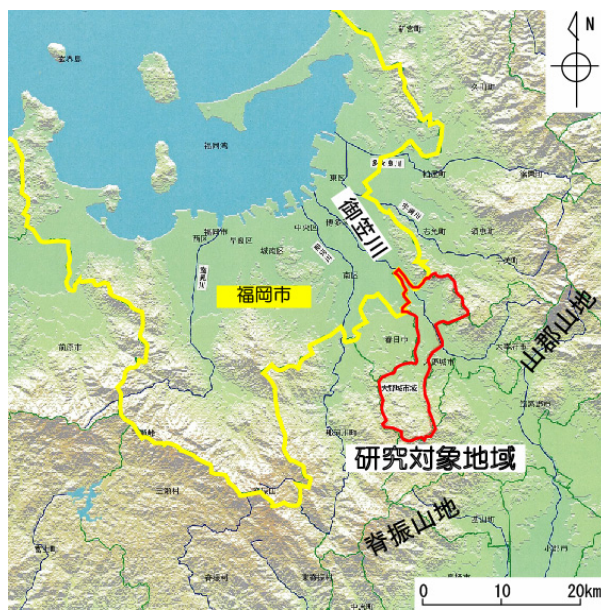

図-1＼cjkstart調查対象地域位置図
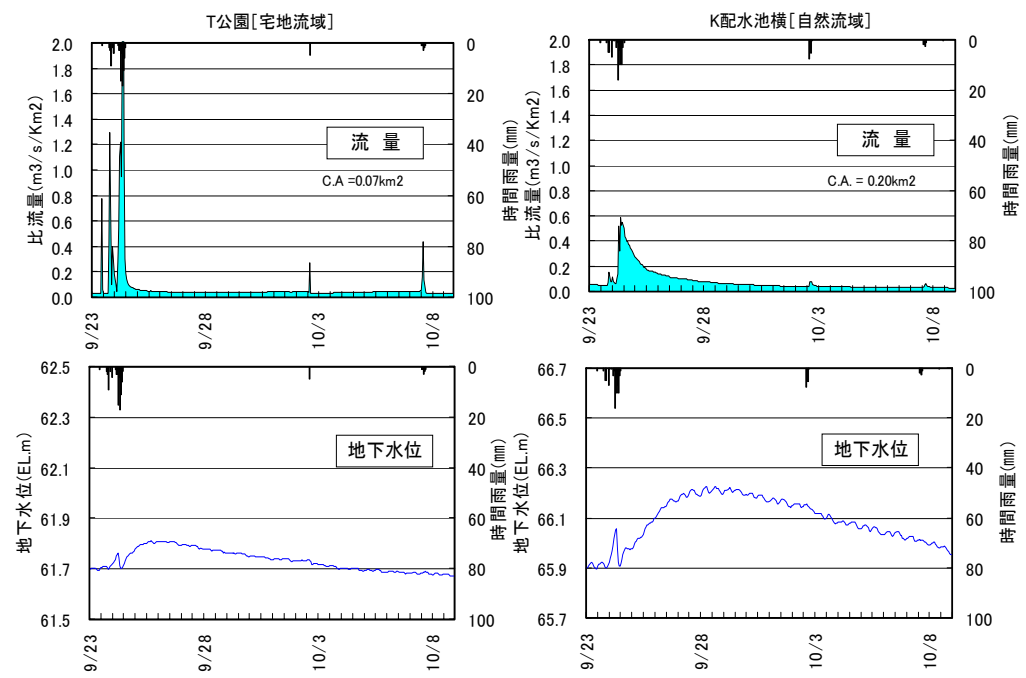

図-3 土地利用の違いによる降雨流出特性（1999 年 9 月 24〜25 日）

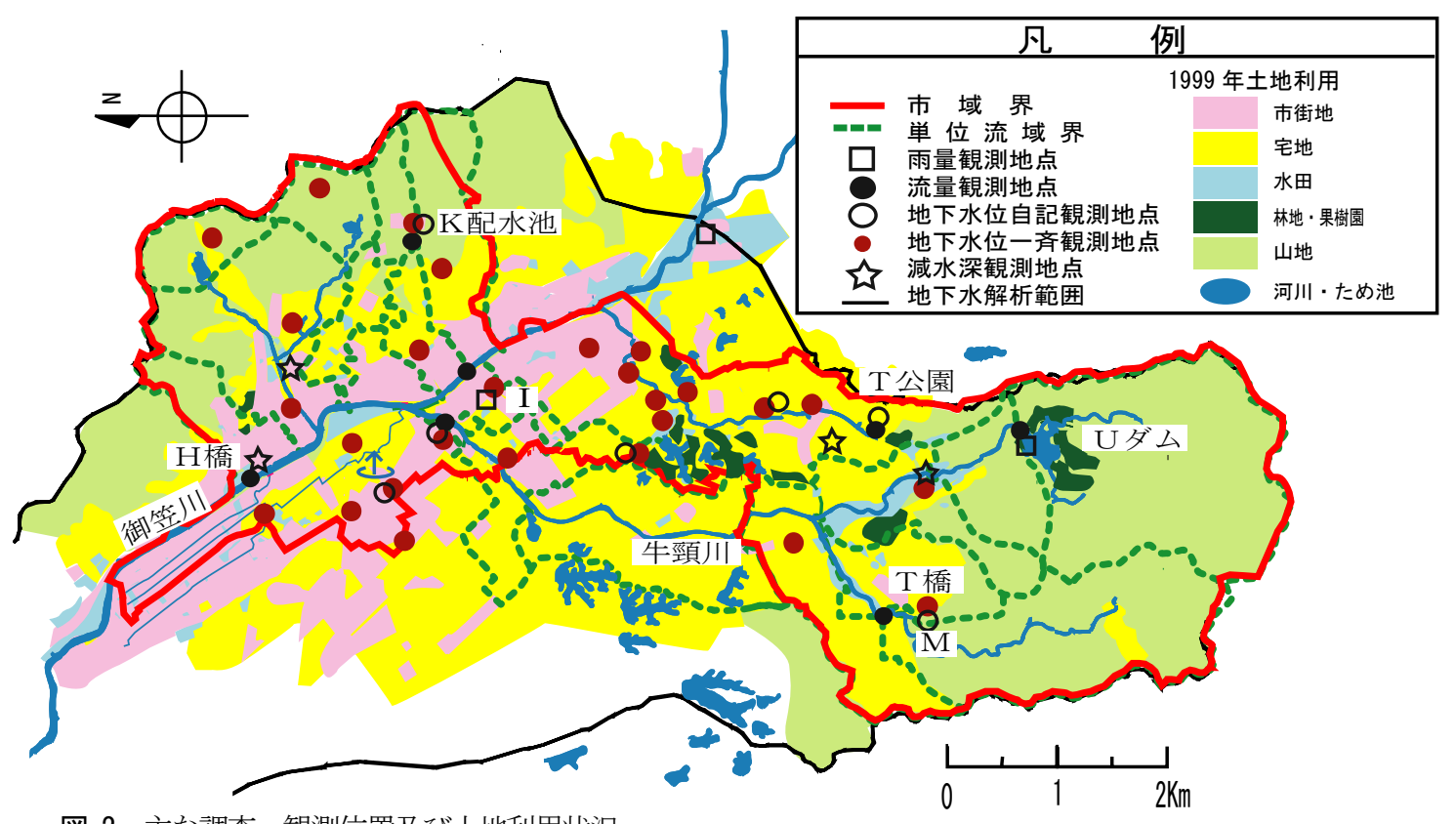

図-2 主な調査・観測位置及び土地利用状況

\section{3. 調査概要と土地利用の違いによる流出特性}

研究対象地域の水循環機構を把握するために行った 主な調査は, ボーリング調査, 地下水位観測, 流量観測, 水田の減水深調査等で，これらの調査・観測位置と 1999 年の土地利用状況を図-2 に示す.

同じ花崗岩類が分布する市域内で森林が残る「自 然流域」の K 配水池（C.A.20ha） と丘陵斜面を造成 して，宅地化された「宅地流域」の T 公園（C.A.7ha） で，流量と地下水位を同時観測した結果を図-3に示 す.流量観測地点は, コンクリート三面張り水路で, 三角堰により観測した。図-3 によると $\mathrm{T}$ 公園では, 宅地化が進むと,「自然流域」の K 配水池に比べて, 洪水のピーク流量が増大するとともに, ピーク発生
後の流量減少が速やかである。

これに対応して, 地下水位は, 宅地化が進むと表 面流出成分が増大し, 地下水涵養量が減少する分, その上昇量が「自然流域」の K 配水池に比べて小さ くなることが分かる.

\section{4. 水循環モデルの概要}

市域内の地下水を含めた水収支を評価するために は, 市域内一の地下水流入量と流出量を推算する必 要がある。このため, 調査の初期段階に得られる限 られた調査データを用いて, 市域全体を解析対象と しながらもモデル構築が比較的容易で, 現況の土地 利用を考慮した「流出一涵養モデル」と「地下水流動 モデル」を組み合わせた水循環モデルを提案する. 


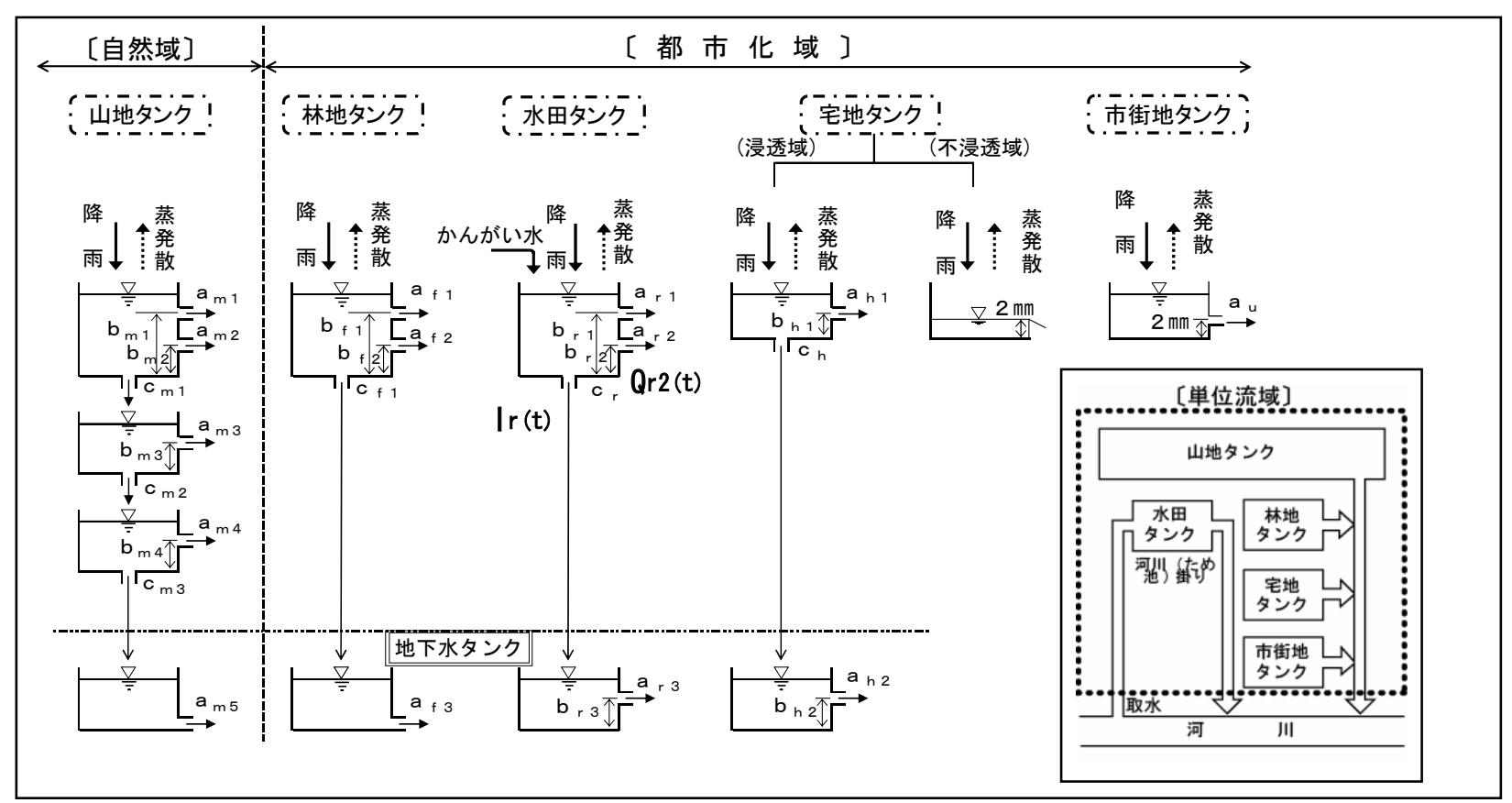

図-4 土地利用形態別タンクモデルの構造

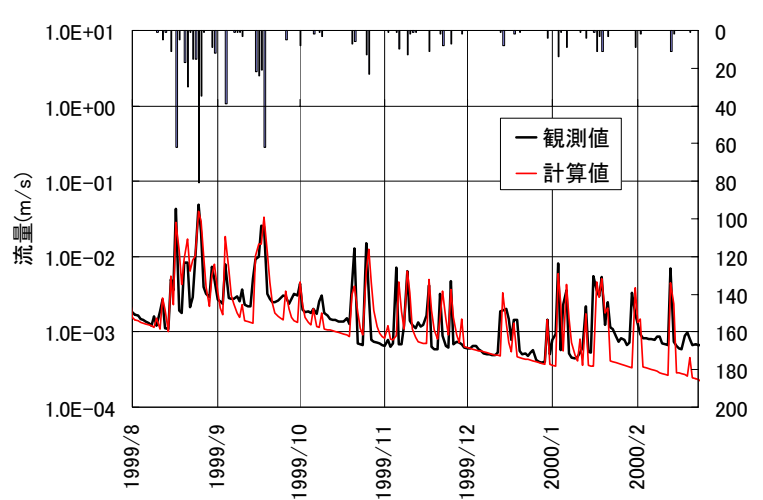

図-5 宅地タンクモデルの同定結果

「流出-涵養モデル」は, 降雨の流出ならびに地表 面浸透が，地下水面まで達する間の時間遅れをタン クモデルで表現するもので，最下段タンクを地下水 タンクとし，ここへの浸透量を地下水涵養量とした。

「地下水流動モデル」は, この地下水涵養量を入力 值とする三次元地下水解析モデルである.

\section{5. 流出-涵養モデル}

\section{（1）土地利用形態別タンクモデル}

流域を単位流域に分割して，その単位流域内に 5 種類の土地利用形態別に, 図-4に示すような構造の タンクモデルを設定した。

\section{a）山地タンク及び林地タンク}

山地タンクには，菅原の 4 段タンクモデルを採用 した. 一般的には, 第 3, 4 段タンクが地下水流出に 対応しているとされているが, 山地部に位置する $\mathrm{M}$ 地点の大雨後の地下水位が, 上昇から低下寸るまで
に，2〜3 ケ月間要していることから，第 4 段タンク を主たる地下水流出成分に寄与する地下水タンクと した. タンク定数は， $\mathrm{U}$ ダム流域流入量、 $\mathrm{K}$ 配水池 及び $\mathrm{T}$ 橋地点の観測流量データを用いて設定した。

林地タンクは，丘陵地から平地部にかけて，都市 化域内に自然地で残存している部分を林地とし, 直 列 2 段型のタンクモデルを採用した。 林地タンクの 第 1 段タンクは，山地タンクモデルの第 1 段タンク を目安に設定した。

\section{b) 水田タンク}

水田タンクモデルについては, 冨田らの研究があ $3^{3)}$. 浸透孔係数 $\mathrm{C}_{\mathrm{r}}$ と流出孔係数 $\mathrm{a}_{\mathrm{r} 2}$ の推定に, 減 水深調査から求まる水田浸透量を用いた。水田浸透 量は, 畦畔浸透量を表す $\mathrm{Q}_{\mathrm{r} 2}(\mathrm{t})$ と田面鈶直浸透量を 表わす $\mathrm{I}_{\mathrm{r}}(\mathrm{t})$ の和で表されることから，水田浸透量= 減水深一蒸発散量 $=\mathrm{Q}_{\mathrm{r} 2}(\mathrm{t})+\mathrm{I}_{\mathrm{r}}(\mathrm{t})=\left(\mathrm{h}-\mathrm{b}_{\mathrm{r} 2}\right) \cdot \mathrm{a}_{\mathrm{r} 2}+$ $\mathrm{h} \cdot \mathrm{C}_{\mathrm{r}}$ の関係式を用いた。 両係数は, 水田土の透水 性が一様として, $\mathrm{C}_{\mathrm{r}}=\mathrm{a}_{\mathrm{r} 2}$ と仮定すると, 減水深調 査データを上式に用いて $\mathrm{C}_{\mathrm{r}}=\mathrm{a}_{\mathrm{r} 2}=0.49 /$ 日となる. ここに、減水深調査データは, 減水深 $=28 \mathrm{~mm} /$ 日, 蒸 発散量 $=3.4 \mathrm{~mm} /$ 日（かんがい期平均值），水田水深 $\mathrm{h}=30 \mathrm{~mm}$ (上段と下段横流出孔高の中間に水位を仮 定), $\mathrm{b}_{\mathrm{r} 1}=50 \mathrm{~mm}, \mathrm{~b}_{\mathrm{r} 2}=10 \mathrm{~mm}$ (経験值) 3)である.

\section{c）宅地タンク及び市街地タンク}

丘陵地に広がる大規模住宅団地は，戸建住宅が大 部分であることから，宅地域からの流出特性を浸透 域と不浸透域（建屋部や舗装道路等）とに分け，不 浸透域面積率を導入して，それぞれからの流出特性 を反映させる並列タンク構造とした. タンク定数は, $\mathrm{T}$ 公園地点の流量観測データを用いて設定した.

浸透域タンクは，第 1 段タンクに一つの流出孔を 


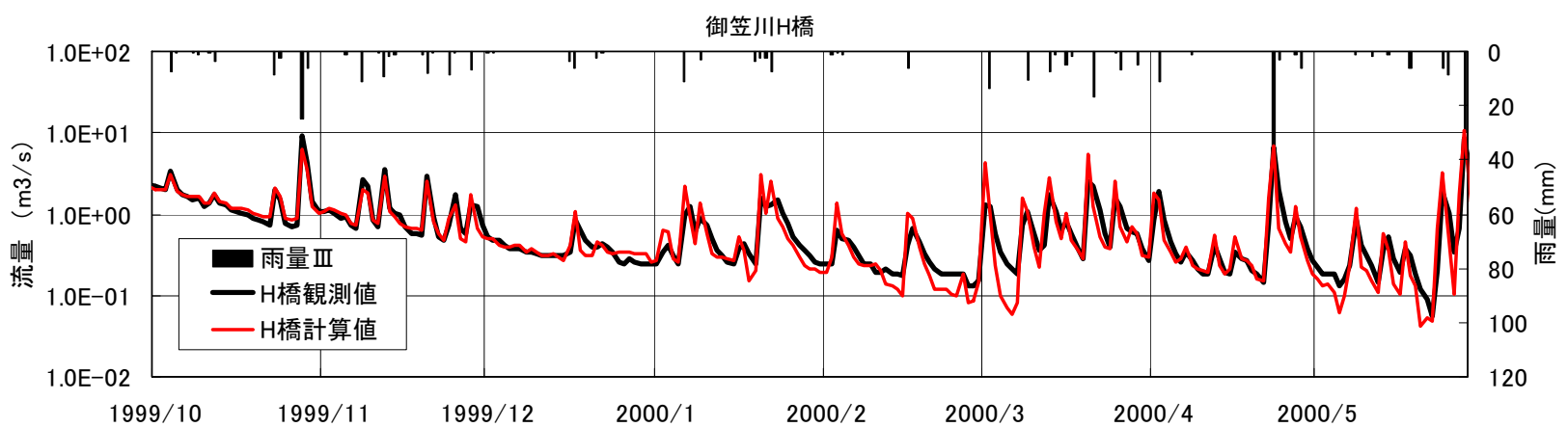

図-6 流出-涵養モデルの検証結果

表-1 帯水層区分と透水係数

\begin{tabular}{|c|c|c|c|}
\hline 帯水層区分 & & 層名 & $\begin{array}{l}\text { 透水係数 } \\
(\mathrm{cm} / \mathrm{sec})\end{array}$ \\
\hline \multirow{3}{*}{ 堆積層 } & \multicolumn{2}{|c|}{ 住吉層 (現河床堆積物) } & $1 \times 10^{-3}$ \\
\hline & \multicolumn{2}{|c|}{ 阿蘇火砕流堆積物 } & $5 \times 10^{-5}$ \\
\hline & \multicolumn{2}{|l|}{ 須崎層 } & $1 \times 10^{-4}$ \\
\hline \multirow{2}{*}{ 基盤岩 } & \multirow{2}{*}{ 花崗岩 } & 風化層 & $4 \times 10^{-5}$ \\
\hline & & 弱風化～新鮮部 & $4 \times 10^{-6}$ \\
\hline
\end{tabular}

有する 2 段型のタンクモデルとした.

当該地点集水域での不浸透域面積率は 0.75 で，一 般市街地の流出係数相当である. 不浸透域タンクの 越流口高さは, 降雨の凹地貯留による損失高さを表 わし, 一降雨当たりの凹地貯留量相当として $2 \mathrm{~mm}^{4}$ とした。観測流量とタンクモデルの同定結果を図-5 に示寸。無降雨期間に計算值の方が低くなる傾向が あるが，降雨期間の流出特性は，概ね表現できてい る.また, 市街地タンクは, 流出孔のタンク底から の高さを同様に $2 \mathrm{~mm}$ とする 1 段型を採用した。

\section{（2）モデルの検証}

降雨量は，近傍の雨量観測所日雨量を用いて，各 単位流域毎に, ティーセン分割係数により算出した 流域平均日雨量を用いた。 日蒸発散量は，福岡管区 気象台の気象データを用いて Penman 法により求め た。 不浸透域の日蒸発量は, 前記の凹地貯留量相当 として以下のように設定した.

a) 日雨量が $2 \mathrm{~mm} /$ 日以上のとき：日蒸発量 $=2 \mathrm{~mm}$

b) 日雨量が $2 \mathrm{~mm} /$ 日以下のとき：その日の雨量全 量が蒸発

御笠川の $\mathrm{H}$ 橋流量で検証した結果を図-6 に示す. 全体的な流出特性は，御笠川本川の流量の影響（流 量比約 80\%）を受けるものの概ね表現できている.

\section{6. 地下水流動モデル}

\section{（1）帯水層モデル}

本地域の花崗岩類は, 近傍の採石場露頭や U ダム
表-2 GIS を用いた水循環モデルレイヤーデータ

\begin{tabular}{|c|c|c|}
\hline モ デル & レイヤーデータ & データ内容 \\
\hline \multirow{3}{*}{$\begin{array}{c}\text { 流出－涵養 } \\
\text { モデル }\end{array}$} & 水文·気象 & 降水量, 蒸発散量 \\
\hline & 土地利用 & $\begin{array}{l}\text { 山地, 林地(果樹園含), 水田, 宅地 } \\
\text { (学校・荒れ地), 市街地(商業施設・ } \\
\text { 宅地[高層]·道路) }\end{array}$ \\
\hline & 涵養量 & $\begin{array}{l}\text { 流出-水涵養モデルにおける地下水夕 } \\
\text { ンクへ浸量 }\end{array}$ \\
\hline \multirow{4}{*}{$\begin{array}{l}\text { 地下水流動 } \\
\text { モデル }\end{array}$} & 河川・湖水面 & 水位境界条件，河床・湖水面標高 \\
\hline & 井戸 & $\begin{array}{l}\text { 家庭井戸(注)・水源井戸の位置・深 } \\
\text { 度・揚水量 }\end{array}$ \\
\hline & 地幋標高 & 50mメッシュ国土数值情報 \\
\hline & 帯水層 & $\begin{array}{l}\text { 地層種別と各層水理定数 (透水係数- } \\
\text { 比貯留係数. 空隙率) }\end{array}$ \\
\hline
\end{tabular}

(注) : 家庭井戸揚水量 $\mathrm{Q}=128 \mathrm{~L} /$ 人・日 $\times 1$ メッシュ内世帯数 $\times$ 当該 行政区井戸保有率 $\times$ 当該行政区一世帯平均構成員数 アンケート調査結果：一人一日当たりの地下水使用量(128 L/ 人・日), 各行政区毎の井戸保有率

基礎調査用の長尺ボーリングコア等を観察した結果, マサ化を伴う一般的な花崗岩地帯の風化形態を示寸 ことが判明した。帯水層は, 表-1のように, 堆積層 と基盤岩であり，基盤岩は風化層と弱風化〜新鮮部 の 2 層構造とした. 地表踏查の結果, 風化層厚さと 斜面勾配の関係が認められたので，風化層厚さは以 下の a) c)のように設定した. このため, 弱風化〜 新鮮部の厚さは, 風化層下限面〜解析領域底面とな る. また, 堆積層では各地層の厚さが帯水層厚さと なり, 地質断面から各地層の分布厚さを設定した。

a) 山地斜面部（35 程度以上）; 風化層厚 $=15 \mathrm{~m}$

b) 丘陵地 $\left(15^{\circ}\right.$ 程度以下） ; 風化層厚 $=35 \mathrm{~m}$

c) 平地部（堆積層下）；風化層厚 $=20 \mathrm{~m}$

各帯水層の透水係数は, 既往透水試験資料より, 表-1に示寸ように設定した. 解析範囲は, 水収支域 である市域を含み, 分水嶺で囲まれた流域界とした。 流域界を不透水壁境界とするが，御笠川の最上流部 と最下流部の横断境界は, 河川水位を与える水位固 定境界とした。深度的には，平地部における $200 \mathrm{~m}$ の深井戸の存在を考慮して, EL. $-400 \mathrm{~m}$ までとした。

\section{（2）モデルの検証}

広域の地下水解析は、50m メッシュで行い, GIS を利用したレイヤーデータとして，表-2に示すよう な各種データをモデルに組み込んだ。 


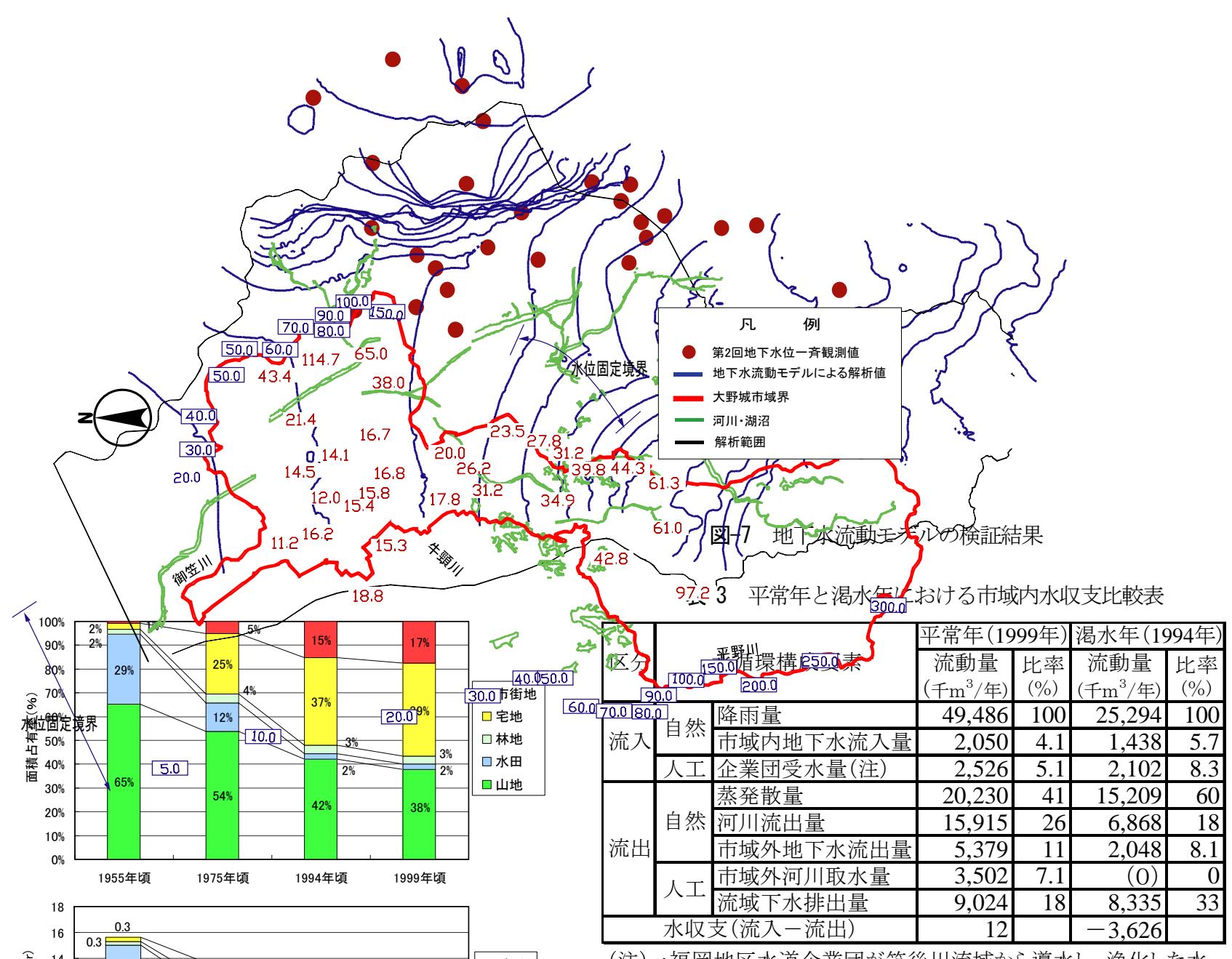

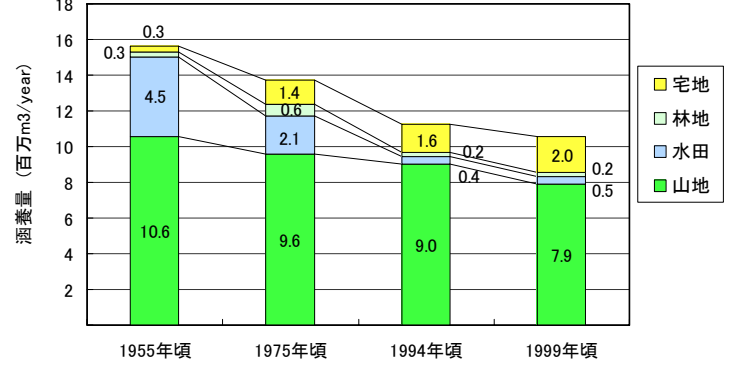

図-8 都市化の進展に伴う年涵養量の推移

検証值として，地下水位一斉観測データ（2000 年 2 月）を用いた検証結果を図-7 に示す。市域北部の 左岸平地部は, $2 \mathrm{~m}$ 以内の誤差で再現出来ている. 右 岸山地部については，計算值が低くなっているが， 要因としては, 山地部の雨量観測所 (年降雨量で平 地部より約 $20 \%$ 多い）がなく, ティーセン分割によ り, 流域平均雨量が実際より低く評価され, 涵養量 が少な目に推算されたためと考えられる. 市域中央 部の適合度は概ね良好である。

\section{7. 都市化による水循環量への影響}

\section{（1）涵養量}

都市化の進展を調べるため, 高度経済成長期前の
(注): 福岡地区水道企業団が筑後川流域から導水し, 浄化した水 を当市が受水した量で，「福岡県の水道 平成11年度」による

1955 年頃, 高度経済成長期の 1975 年頃, バブル経 済破壊後の 1994 年頃ならびに経済低迷期に入った 1999 年頃を代表期に選定して, 各代表期の国土基本 困（1/25,000）から土地利用面積を計測した。この土 地利用に水循環モデルを適用して, 都市化の進展に 伴う年涵養量の推移を調べたものが図-8である（年 降雨量が平常年の值を示す 1999 年( I 観測所 : 1710 mm/年)の日雨量を用いて計算）。1955 年頃は, 山地, 水田, 林地の自然系が市域全体の 97\%を占めていた ものが, 1999 年頃では, $43 \%$ と半減しており, 特に 水田は，2\%と激減している。 それに対応して，市街 地と宅地が $56 \%$ を占め, この 40 年間で急激に都市 化が進展したことが分かる.この都市の進展に伴い, この間の年涵養量が約 32\%減少したと推定される. また，水田からの年間涵養量が 1955 年頃には, 29\%あつたものが，1999 年頃には 4\%に激減してい る. 1980 年代前半に, 御笠川左岸の湧水井戸が枯渇 したことを考慮すると, 水田が有する地下水と河川 の水環境維持機能の果たす役割が大きいことを示唆 している. 

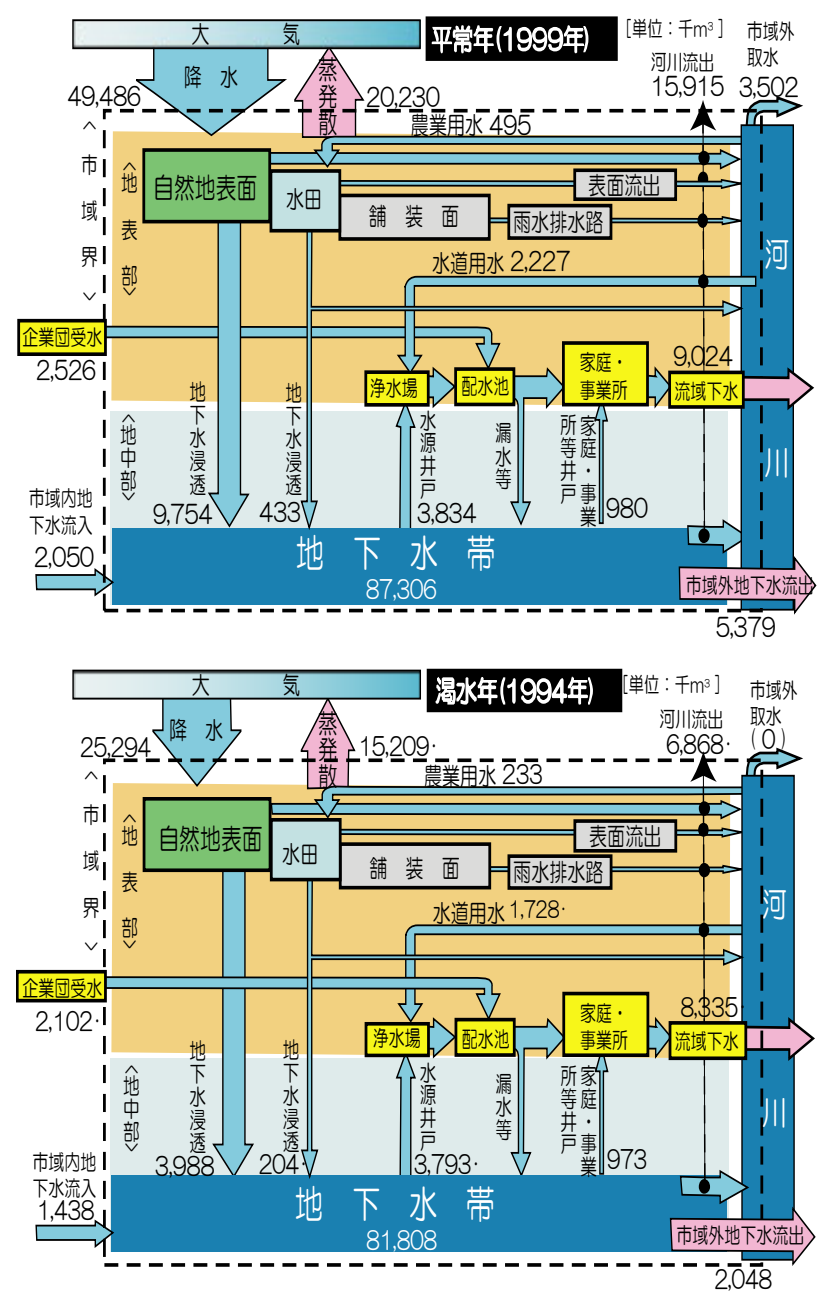

図-9 平常年と渇水年における市域内水収支比較図

\section{（2）水収支}

年降雨量評価による平常年（1999 年，I 観測所： $1710 \mathrm{~mm} /$ 年) と渇水年 (1994 年, I 観測所 : $737 \mathrm{~mm} /$ 年）について，年間水収支を比較したものを表-3, 図-9 に示寸.なお，表-3に示す水循環構成要素のう ち，人工系には当市の統計資料を用い，自然系には 今回提案した水循環モデルを用いて流動量を求めた. 水収支特性は, 以下のとおりである。

a) 平常年の水収支は，バランスしているが，渴水年 では，マイナスである。地下水取水は，市域内の 地下水貯留量の消費により補われている。すなわ ち, 渴水年には, 表流水取水量は減少したが, 地 下水取水量は, 平常年とほぼ同程度確保できた。

b) 地下水は, 地形条件と東西に細長い市域形状によ り, 市域内で涵養された地下水も市域外一流出し がちで, 地下水流出量が流入量の 2.6 倍と多く, 地下水資源の利用面からは，不利な条件にある. したがって, 市域内の水資源賦存量は, 必ずしも 恵まれてはいない。

c) 水道水の $29 \%$ (1999 年)を占める企業団受水は, 市 域外から導水された水で，市域内で年間 7,041千 $\mathrm{m}^{3}$ 取水された水も合わせて, 使用後は流域下水道 により市域外にバイパスされ，市域内の河川への 復帰はないことから, 水の循環性は断たれている.

\section{8.おわりに}

本研究では，市域全体を対象とした水収支による 水資源賦存量の評価手法として, モデル構築が比較 的容易な水循環モデルを提案した. この水循環モデ ルの研究成果として次のような知見が得られた.

(1)「流出-涵養モデル」では，単位流域ごとに 5 種 類の土地利用形態別のタンクモデルを組み合わせ ることにより，自然域と都市化域の混在域におい ても流出と地下水涵養特性の表現が可能である.

（2）「地下水流動モデル」では，「流出-涵養モデル」 から求められた土地利用形態ごとの涵養量を現況 の土地利用に合わせて平面的に分布させて与える ことにより, 現況地下水位を精度良く再現できた。

（3）「流出-涵養モデル」と「地下水流動モデル」を 組み合わせた水循環モデルでは，表流水だけでな く地下水流動も含めた広域的な水収支の把握が可 能である.

(4) この水循環モデルは, モデル定数を極力少なく し, 河川流量や地下水位等の基本的な調査データ により，比較的容易にモデル構築が可能である. このことから，水源井を新設する場合の事前影響 評価, 地下水管理や水環境保全等の水行政施策検 討の支援ツールとしても有効である.

\section{参考文献}

1) 河原能久, 未次忠司, 賈仰文, 倪广恒 : 都市河川 流域の水循環解析，土木技術資料，Vol.41-12, pp38-43， 1999

2) 小尻利治，木内陽一：Hydrological River Basin Environment Assessment with Multi-layer and Multi-mesh(Hydro-BEAM), 流出モデルの比較・評 価に関する研究報告, 実践水文システム研究会, 2000.5

3) 冨田正彦, 小林慎太郎, 丸山利輔: 複合タンクモ デルによる広域水収支解析〜2. 複合タンクモデ ルの運用〜, 農業土木学会誌, 第 47 巻, 第 3 号, pp189-194, 1979

4) 安藤義久, 高橋裕, 有賀茂, 金尾健司 : 丘陵地の 中小河川流域の水循環機構と都市化によるその 変化, 第 26 回水理講演会論文集, pp251-260, 1982.2 